Air, water, land: mexican-origin adolescents' perceptions of health and the environment

\title{
Ar, água e terra: percepções de saúde ambiental de adolescentes de origem mexicana
}

\author{
Aire, água y tierra: percepciones de salud ambiental de adolecentes de origen mexicana
}

\author{
Carolyn M. Garcia', Marcelo Medeiros"
}

\begin{abstract}
Latino adolescents are the fastest growing population sub-group in the United States (U.S.). Health disparities exist between Latino teens and the majority population of adolescents in the U.S. as evidenced by rates of health problems including asthma and depression; environmental factors contribute to these concerning trends. The objective is to describe how environmental influences are perceived by Mexican-origin immigrant adolescents. A focused ethnography guided by an ecological framework and symbolic interactionism was conducted using 1-to-1 interviewing, participant observations, and visual narratives created using disposable cameras. Fourteen participants took "pictures of life as an immigrant Latino adolescent, with a focus on health." Interview and photograph data were organized and analyzed using Atlas.ti software. Four themes were identified: "Garbage is everywhere," "Work hurts me," "Air we breathe," and "Relaxation in nature." Findings demonstrate comprehensive appreciation for risk and protective environmental influences on health. Nurses can utilize findings to reinforce the need to holistically assess Latino adolescent health, examining risk and protective environmental factors in the context of social determinants of health and health disparities. Findings support use of photovoice in research and that nursing theory can advance the ecological model and understanding of environmental health influences on disparities and well-being.
\end{abstract}

Key words: Immigration; Adolescent Health; Environmental Health; Qualitative Research.

\section{RESUMO}

Adolescentes latinos constituem um subgrupo que cresce rapidamente nos EUA. Disparidades entre os adolescentes latinos e a maioria da população de adolescentes nos EUA são evidenciadas por taxas de morbidade incluindo asma e depressão; fatores ambientais contribuem para estas tendências. Objetivo do estudo é descrever como as influências ambientais são percebidas por adolescentes imigrantes de origem mexicana. Pesquisa etnográfica orientada no referencial ecológico e interacionismo simbólico na condução de entrevistas individuais, observação participante, e narrativas visuais por meio de câmeras descartáveis. Quatorze participantes "fotografaram suas vidas como adolescentes latinos imigrantes, focando a saúde". Entrevistas e fotografias foram organizadas e analisadas utilizando 0 software Altas.ti ${ }^{\circledR}$ emergindo quatro temas: "Lixo está em todos os lugares", "O trabalho me machuca", "O ar que respiramos", e "Relaxamento na natureza". Os resultados demonstram a compreensão detalhada do risco e influências protetoras do ambiente na saúde. Enfermeiros podem utilizar os resultados reforçando a necessidade de avaliação integral da saúde do adolescente latino, examinando fatores de risco e proteção ambiental no contexto dos determinantes sociais de saúde e disparidades em saúde. Resultados sustentam uso da foto-voz em pesquisa e possibilidades de avanço nas teorias de enfermagem no modelo ecológico para compreender influências da saúde ambiental nas disparidades sociais.

Palavras chave: Migração Internacional; Saúde do Adolescente; Saúde Ambiental; Pesquisa Qualitativa.

\section{RESUMEN}

Adolescentes latinos constituyen subgrupo que crece rápidamente en los EEUU. Disparidades entre adolescentes latinos y la mayoría de la población de adolescentes en EEUU son evidenciadas por índices de morbidez incluyendo asma y depresión; factores

PhD, MPH, RN Assistant Professor, Center for Adolescent Nursing, School of Nursing, University of Minnesota. Minneapolis, MN 55455. USA. Email: garcia@umn.edu

" Doutor em Enfermagem. Professor Associado da Faculdade de Enfermagem da Universidade Federal de Goiás. Goiânia, GO. Email: marcelo@fen.ufg.br 
Garcia CM, Medeiros M. Air, water, land: mexican-origin adolescents' perceptions of health and the environment. Revista Eletrônica de Enfermagem [serial on line] 2007 Set-Dez; 9(3): 574-587. Available from: URL: http://www.fen.ufg. br/revista/v9/n3/v9n3a02.htm

ambientales contribuyen para estas tendencias. Objetivo es describir como las influencias ambientales son percibidas por adolescentes inmigrantes de origen mexicana. Investigación etnográfica orientada por referencial ecológico e interacionismo simbólico en la conducción de entrevistas individuales, observación participante, y narrativas visuales por medio de cámaras descartables. Catorce participantes "fotograbaran sus vidas como adolescentes latinos inmigrantes, centrando la salud". Entrevistas y fotografías fueron organizadas e analizadas utilizándose el software Atlas.ti ${ }^{\circledR}$ emergiendo cuatro temas: "la basura asta en todos lugares", "El trabajo machuca", "el aire que nosotros respiramos", y "relajamiento y naturaleza". Los resultados demuestran

\section{STUDY RATI ONALE}

Latino adolescents are the fastest growing population sub-group in the United States (U.S.) and are part of the largest ethnic minority group. Health disparities exist between Latino teens and the majority population of adolescents in the U.S. as evidenced by rates of physical and mental health problems including asthma and depression ${ }^{(1,2)}$. Social determinants of health, notably poverty, result in Latino adolescents residing where environmental risks are prevalent while environmental assets may be lacking (3,4). The influence of environmental factors, harmful and protective, is recognized by nurses but how the environment is perceived by Mexican-origin immigrant Latino adolescents has not been documented previously. Their perceptions can provide useful foundational knowledge for developing successful health assessment and promotion nursing initiatives.

For all adolescents, physical and mental development can be negatively or positively influenced by environmental factors (5-7). comprensión detallada del riesgo e influencias protectoras del ambiente en la salud. Enfermeros pueden utilizar los resultados reforzando la necesidad de evaluación integral de la salud del adolescente latino, examinando factores de riesgo y protección ambiental en el contexto de los determinantes e disparidades sociales de salud. Sustentan el uso de la fotografía en investigaciones y posibilidades de avanzos en teorías de enfermería en el modelo ecológico para comprender influencias de la salud ambiental en las disparidades y bien estar social.

Palabras clave: Migración Internacional; Salud del Adolescente; Salud Ambiental; Investigación Cualitativo.

Immigrant Latino adolescents experience health disparities resulting from complex causes including social determinants of health such as poverty ${ }^{(8,9)}$. Affordable housing in the U.S. for those in poverty is often situated in tenuous environments within urban settings; for immigrant Latino adolescents this increases their exposure to environmental pollutants that contribute to development or exacerbation of health problems such as asthma ${ }^{(1)}$. Lack of access to safe recreational environmental resources in conjunction with neighborhood risks such as gang presence, crime, and illegal drug sales together compound the potential for problems such as depression or violence ${ }^{(2,10)}$. Moreover, concerning rates of obesity among Latino adolescents are due to complex reasons that, for those living in low-SES areas, include the lack of safe access to venues for physical activity ${ }^{(11)}$.

For those youth who are employed, occupational hazards comprise an additional layer of environmental risk though there are inherent economic benefits. Furthermore, for the immigrant Latino adolescents who are 
Garcia CM, Medeiros M. Air, water, land: mexican-origin adolescents' perceptions of health and the environment. Revista Eletrônica de Enfermagem [serial on line] 2007 Set-Dez; 9(3): 574-587. Available from: URL: http://www.fen.ufg. br/revista/v9/n3/v9n3a02.htm

migrant and follow agricultural seasons across the country, environmental risks also include occupational hazards such as pesticide exposure ${ }^{(3)}$.

Nurses practice in settings that are accessed by immigrant Latino adolescents; namely, school- and community-based health care centers. It is important that nurses are able to recognize and assess for environmental risk and protective factors. A starting point upon which to build this awareness is to gain understanding of how immigrant Latino adolescents' perceive environmental influences on their health. This knowledge can inform practice and research initiatives to minimize risks and maximize assets within their experienced physical environment.

\section{LITERATURE REVIEW}

Research on environmental exposures and the subsequent impact on this developing phase of adolescence provides foundation understanding of the extent of harm that can occur during this period of rapid physiological growth ${ }^{(5,6)}$. Operating with this understanding, Golub (2000) describes specific effects of toxicants such as disrupting adolescent biological maturation and function because of the uniqueness of this developmental period. Examining beyond general or random physical environmental exposures, Golub highlights the voluntary and involuntary environmental exposures that make adolescents particularly susceptible to harmful effects. Specifically noted are voluntary exposures such as substance use or experimentation and involuntary exposures to toxicants in the workplace (7). This literature provides foundational understanding but is limited in that it is not specifically describing Latino adolescents.

Because many Latino children and adolescents work in migrant agricultural settings, researchers examining environmental exposures in Latino youth have specifically targeted these high-risk exposure areas. Salazar, Napolitano, Scherer, and McCauley conducted a qualitative, descriptive inquiry exploring the perceptions of Latino adolescent farm workers regarding their pesticide exposures, specifically (3).

Using a focus group methodology based on an ecological framework, they gained awareness of the adolescents' perceptions regarding their susceptibility to illness because of the pesticide exposure, their knowledge of hazards, and the barriers they felt regarding other employment possibilities. The participants were not necessarily recently immigrated, so the findings, while useful and insightful, are not readily transferable. Another qualitative study conducted with Latino migrant school-aged children focused on their perceptions of health ${ }^{(4)}$. Specific to migrant Latino youth, the findings from this focus group study highlighted health perceptions including acculturation issues and environmental influences.

Study recommendations centered on improving the culturally competent care of pediatric nurses. Both studies provide understanding but because they had not been conducted with recently immigrated older Latino adolescents and were focused on a migrant population, they could not be used to move beyond a descriptive study design. Thus, the proposed study complimented existing work and was designed to contribute new 
Garcia CM, Medeiros M. Air, water, land: mexican-origin adolescents' perceptions of health and the environment. Revista Eletrônica de Enfermagem [serial on line] 2007 Set-Dez; 9(3): 574-587. Available from: URL: http://www.fen.ufg. br/revista/v9/n3/v9n3a02.htm

understanding about a rapidly growing population sub-group: immigrant Latino adolescents.

Beyond the physical environmental risks and exposures literature, there is a growing body of literature informing understanding of the role that social determinants of health play in affecting the health and health disparities experienced by adolescents. For youth in poverty, the environmental absence of resources such as playgrounds or parks has substantial influence on their ability to be physically active and subsequently, at lower risk for obesity or diabetes ${ }^{(12)}$.

Both diseases are disproportionately affecting the Latino community; understanding how social determinants of health, including poverty, and related environmental risks are associated with these diseases could lead to innovative preventive nursing interventions. Further, physical environmental characteristics have been shown to contribute to a developmental-ecological model of violence for Latino adolescent boys living in poor urban areas (10). Understanding how Latino adolescents view the environment surrounding them will contribute to this developing knowledge.

Finally, varied qualitative and photovoice methodologies have been employed with Latino adolescents to ascertain perceptions of health and illness ${ }^{(3)}$. The richness of descriptive data obtained make these methods useful in exploratory level studies designed to establish a frame of reference upon which to inform practice and future research. In particular, photovoice has been used in the Latino community to gain perceptions of topics such as immigration or health-seeking behaviors including prenatal care ${ }^{(13)}$.

\section{CONCEPTUAL FRAMEWORK}

Bronfenbrenner's ecological theory was the guiding framework for the study design and data analysis (14). Though the adolescents themselves comprised the main source of primary data, the ethnographic design incorporated researcher data including observation, reflective journaling, and field notes.

Further, symbolic interactionism informed the study design; emphasis is on the meanings of an experience attributed by the individual. In this way, an experience can be positive for one individual, similar or negative for another person in the same or different cultural context. Applied to this study, symbolic interactionism necessitated a follow-up with the photographs so that the adolescent could describe what she/he was thinking when taking the picture.

\section{Purpose}

The original study aims were to describe immigrant Latino adolescents' perceptions of healthy and unhealthy influences and their experiences accessing the U.S. health care system. General perceptions of health and specific perceptions of mental health have been reported elsewhere ${ }^{(15,16)}$. The purpose of this article is to describe the perceived healthy and unhealthy environmental influences of immigrant Latino adolescents in their own words and pictures.

\section{METHODS}

\section{Study design}


Garcia CM, Medeiros M. Air, water, land: mexican-origin adolescents' perceptions of health and the environment. Revista Eletrônica de Enfermagem [serial on line] 2007 Set-Dez; 9(3): 574-587. Available from: URL: http://www.fen.ufg. br/revista/v9/n3/v9n3a02.htm

This focused ethnography employed oneto-one interviews and photovoice data collection techniques. A focused ethnography is a narrow exploratory study of an area of concern within a community with time- and context-specific boundaries. This methodology contributes understanding that is gained within a context of environment and culture ${ }^{(17)}$. A photovoice strategy was selected to compliment the interview data, which were thought to possibly be limited due to discomfort that can be experienced in an interview setting. An empowering tool, the photovoice methodology has been used in prior research with Latino adolescents; it gives participants the opportunity to contribute data in their own time and space ${ }^{(18,19)}$.

\section{Participants}

Immigrant Latino adolescents were invited to participate if they had arrived into the U.S. no more than three years before the initial interview was conducted; all participants arrived to the U.S. between 2001 and 2003 . Additional inclusion criteria included being between 15 and 20 years of age, selfidentifying as Mexican, and willingness to participate. Fourteen adolescents were purposively recruited from a public charter school and a church using verbal invitation augmented with written information sheets. Both settings have large Latino populations and are located in neighboring urban cities in a mid-western State experiencing rapid Latino population growth. A church was selected to facilitate recruitment of Latino adolescents who may not be attending school because the dropout rate for Latino youth is high.

\section{Data collection}

Following University of Minnesota Institutional Review Board (IRB) approval, a purposive sampling strategy was employed to recruit participants. Verbal explanation of the study and an informational sheet were provided to interested adolescents. The IRB waived the need for active parental consent; an informational sheet was given to parents when they were present or to adolescents to bring home. There was no mechanism to ensure that when the informational sheet was given to the adolescent to bring home, it was in fact delivered to the parent.

Approximately a week lapsed before commencing the study with interested adolescents so parents could contact the PI as desired. There were no parental inquiries over the course of the study. Adolescent verbal assent was obtained before beginning the initial interview; the IRB did not require written assent because it was felt this might limit willingness to participate because of participants possibly lacking legal documentation of residency or citizenship. The assent process addressed content of the photographs and what the PI or research team would be required to report, such as apparent abuse. The initial interview took place where the adolescent preferred; all selected the recruitment site (school or church) for this interview.

The goals of the first semi-structured interview were to elicit the adolescent's health perceptions and his/her experiences accessing the U.S. health care system. At this interview participants completed a demographic questionnaire including a language-based acculturation scale developed for Latinos. The 
Garcia CM, Medeiros M. Air, water, land: mexican-origin adolescents' perceptions of health and the environment. Revista Eletrônica de Enfermagem [serial on line] 2007 Set-Dez; 9(3): 574-587. Available from: URL: http://www.fen.ufg. br/revista/v9/n3/v9n3a02.htm

interview was conducted in English or Spanish according to the participant's preference; a Latino professional interpreter was present at all interviews. Interview lengths ranged from 45 minutes to nearly 2 hours, and all were audio recorded to facilitate verbatim transcription and translation of Spanish into English.

Each adolescent was then given a disposable camera with 24 exposures and instructions to "Take pictures of healthy and unhealthy influences in your life." Participants were asked to complete their photographs within two weeks though on average, the cameras were returned a month after the initial interview. Following film development, a second interview was conducted to ascertain the meanings behind each photograph; key questions asked included "Why did you take this picture?" and "What were thinking of when you took this picture?"

These interviews were also conducted where the participants preferred; for most, this remained the school and church but for a few, the interview took place in their homes. At the end of each second interview, a second assent process was followed to determine which photographs the adolescent would allow the PI to use in public data dissemination activities such as presentations and publications. Because the adolescents gave permission for most photographs to be used, those they did not give permission to use were signed and dated on the back to identify them.

Each participant received a $25 \$$ gift card for Target following the completion of each interview so each adolescent completing both interviews received a total of $\$ 50$. Each participant also received a copy of his/her photographs to keep.

In addition to the interviews and photographs, the PI completed extensive field notes, noting observations and interactions throughout the study process. Journaling by the $\mathrm{PI}$ contributed in-depth reflection on the process and experience of conducting this study. These data were referred to during the analysis of the interview and photograph data in order to provide contextual understanding for some of the findings. These components of the study were important given the non-Latino ethnicity of the PI and the need for maximizing interpretation of data were within the appropriate context. The PI spent extensive time at each study site, participating in various activities in order to gain in-depth understanding of the environment in which the adolescents resided. The PI lives within one of the urban cities and spent time immersing within the local Latino community beginning two years prior to the actual study commencing.

In addition to quality time in the field, reflective journaling, and field notes, the study rigor was strengthened by using triangulation of data sources, consulting method and cultural experts throughout the research process, comparing oral and written interview data, and maintaining an audit trail of process and paperwork.

\section{Analysis}

All interviews were successfully recorded; these were transcribed and translated by a professional not associated with the study. Where questions arose, the transcriber kept the Spanish text in parentheses next to the 
Garcia CM, Medeiros M. Air, water, land: mexican-origin adolescents' perceptions of health and the environment. Revista Eletrônica de Enfermagem [serial on line] 2007 Set-Dez; 9(3): 574-587. Available from: URL: http://www.fen.ufg. br/revista/v9/n3/v9n3a02.htm

English translation for the PI to examine and address with the interpreter, listening to the recorded interview as needed. All interview text and photographs were imported into Atlas. $\mathrm{ti}^{\circledR}$ software to facilitate an inductive coding process.

In total, nearly twenty hours of interview were coded along with 180 pictures. The pictures were coded based on the meanings provided by the adolescents rather than using a pre-identified list of possible codes. As new codes were created to describe interview or photograph data, the previously coded data were re-examined to determine if the new codes were applicable to that data. The assigned labels, or codes, were combined into categories that were organized in a manner that facilitated identifying thematic patterns that aligned with the original study aims. The environmental-focused codes and categories were re-organized in subsequent analysis in order to identify representative environmental themes. These themes, with supportive original data quotations and thick descriptions, are presented below.

\section{RESULTS}

\section{Sample}

The sample $(\mathrm{N}=14)$ included 9 females and 5 males, 15 to 20 years of age $($ mean $=$ 16.6), who emigrated from Mexico within 3 years of being recruited (range $=2$ months to 3 years). They were equally recruited from both settings ( 7 participants from each). Thirteen participants emigrated from Central Mexico with the $14^{\text {th }}$ reporting being from Northern Mexico. Data were not collected regarding whether or not the participants came from urban or rural areas within their State in
Mexico; however, through the interview process many participants described living in Mexico City rather than in rural areas of Mexico. All participants reported attending school in Mexico prior to immigrating. Six participants, all recruited from the church setting, were not in school; of these, four had either graduated or were in the process of being admitted. Five of the 14 were employed; employment settings included retail, construction, and manufacturing. The Bidimensional Acculturation Scale, a languagebased measure of acculturation, reflected the recent immigrant status of the participants. All 14 scored high in their self-reported comfort with the Spanish language; only 5 scored high in their self-reported comfort with English.

Three of the participants did not have their parents living in the U.S.; the other 11 reported living with their parents. Ten of the participants reported living in a household with five or more persons; three reported household size of four and the final participant reported living in a household size of three. Large household sizes are common among the Latino community for cultural and economic reasons. All but two of the participants lived in a house; the two resided in apartments. This was the only indirect measure of economic position and quantitative data do not exist to further understand the economic position of the sample. Photos demonstrated a range of living situations, ranging from photos of housing that appeared to be in low-income parts of the city to photos of organic juice in the refrigerator within a tidy, attractive kitchen.

Three youth did not complete the visual narrative or 2 nd interview. Two of these had 
Garcia CM, Medeiros M. Air, water, land: mexican-origin adolescents' perceptions of health and the environment. Revista Eletrônica de Enfermagem [serial on line] 2007 Set-Dez; 9(3): 574-587. Available from: URL: http://www.fen.ufg. br/revista/v9/n3/v9n3a02.htm

returned to Mexico following the first interview; the third did not return follow-up phone calls.

\section{Thematic overview}

In doing the data analysis, an important point became very clear. The initial interview data from all participants did not include references to environmental health influences with the exception of work related exposures. Indeed, the rich environmental health data came when the participants completed their photovoice project and presented numerous photos of environmental influences, positive and negative. The follow-up interviews reinforced the importance of environmental influences as perceived by the adolescents. The four environmental themes that were identified and are described below include: "Garbage is everywhere", "Work hurts me", "Air we breathe", and "Relaxation in nature". Real participant names have not been used when quotes are provided.

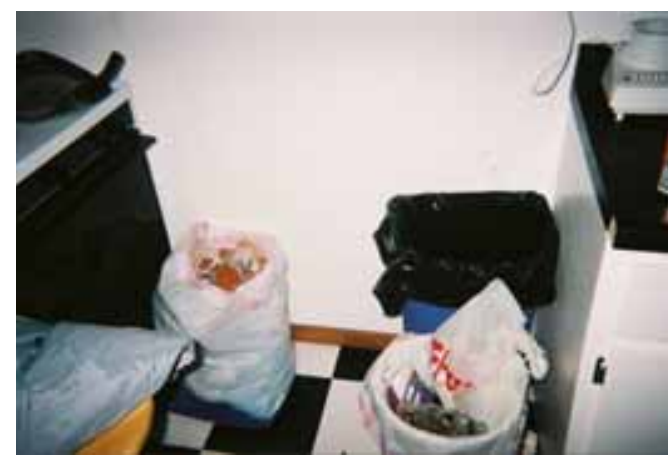

Figure 1: Indoor garbage

Talking about indoor trash, Esmiralda said, "If it is not kept controlled and it is placed in places where people can be contaminated, people can be affected by it and it actually can be bad for your health because you can

\section{Theme I: "Garbage is everywhere"}

Participants portrayed indoor and outdoor garbage, including kitchen trash bags, collection bins, litter on the ground near their homes and in parks. Differentiating organic and inorganic garbage, Liselle shared, "Garbage can be good and bad. I see organic trash as good and I see inorganic trash as bad. The inorganic, as I see, its stuff [that] doesn't dissolve and ends up contaminating the rivers and other parts that actually do affect us health wise." Miguel addressed this as well, stating, "It is non-degradable material. These probably don't smell as much as the degradable ones but they are still polluting. If nobody picks them up they would accumulate." Miguel also addressed the litter in the park and in the lake, "Here is trash in the lake; [it] is really bad. You can't see (pointing to park of a picture of the lake) but if you go there it is really dirty. You can see trash there is really bad. It takes away from the beauty of nature."

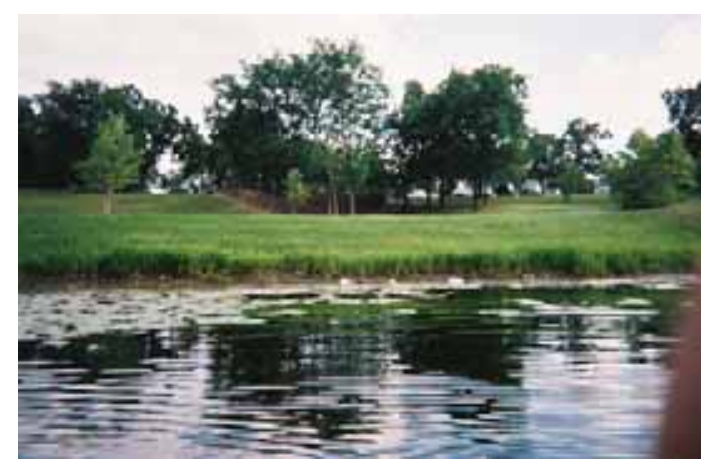

Figure 2: Litter in the lake

actually get sick from it, get an infirmity from it because of the bacteria." Focusing on the bacterial and germ effects, Maria shared, "This is trash, [it] brings germs and bacteria." Talking about a picture of school trash, Flor 
Garcia CM, Medeiros M. Air, water, land: mexican-origin adolescents' perceptions of health and the environment. Revista Eletrônica de Enfermagem [serial on line] 2007 Set-Dez; 9(3): 574-587. Available from: URL: http://www.fen.ufg. br/revista/v9/n3/v9n3a02.htm

shared, "In this picture there is trash strewn and it is not healthy because some times, in other places, it remains for two and three days and that is harmful specially for kids, not so much the adults."

Home trash was photographed primarily in the kitchen or near an outside door; in this context home cleanliness was described as important to health. Flor photographed a clean kitchen setting to emphasize the importance of environmental cleanliness for her health. Miguel described the negative environmental influence of his neighbor's trash, "Here is like really direty in here, that blue house is my neighbor. There is a lot of trash. You can't see the flies but around there is not healthy. Like bad smells. [The poop]. They got a dog."

\section{Theme II: "Work hurts me"}

Participants described harmful work factors ranging from back pain and fatigue to dust and noise exposure. Mario, employed in construction, shared, "I work with sheetrock and there's a lot of dust. And we don't wear any protection. [I feel it] in my nose." Negative coworker influences were noted, "No one uses it [mask] and if I do, they tease me." Also describing the health effects of dust, Javier talked about his work environment, "Where I work there's a lot of dust. And when I get out of work, I feel it in my throat." He also spoke about noise exposure, “There's a lot of noise because we use a machine gun and the tool that cuts in the middle of the tile."

Physical strain evidenced in back pain and headaches resulted from strenuous work and long shifts. Mario described back pain, “Before sometimes I would say, I have to work, but I told my uncle I started to feel back pain.
And he noticed that he was only 26 and had to be careful too." Sagitario described a picture of her dad resting on his back,

Sagitario: "This one is my dad. Because lately he's been working a lot. It's like physically tired. So he came home and laid down and I took the picture."

$\mathrm{PI}$ : "So do you think that his being tired and working too hard is unhealthy?"

Sagitario: “Not healthy because he's getting really tired. Because he can faint or any other thing; it's not good."

Describing another photograph, she shared,

Sagitario: “And because my friend's face. She's sad. But here you could see black eyes (dark shadows under her eyes). Because she sleeps really late and she works."

PI: "Tell me more about the work. Is that a healthy or unhealthy thing?"

Sagitario: "Yes and no. Yes because it's important. And the money helps you. Sometimes no because you overwork yourself. And that's bad. Sometimes you can't do the things you want, cause you have to rest. The first think you want to do is go home and sleep."

Flor, employed in retail, had limited time to eat as noted in this interview exchange with the $\mathrm{PI}$ :

$\mathrm{PI}$ : "Do you have time at work to eat?"

Flor: "They give me ten minutes only."

$\mathrm{PI}$ : "Ten minutes is not enough."

Flor: “I don't know because I only eat snacks. I do eat food, but just a little bit."

PI: "Do you eat food at home?"

Flor: "Yes, but I hardly have time." 
Garcia CM, Medeiros M. Air, water, land: mexican-origin adolescents' perceptions of health and the environment. Revista Eletrônica de Enfermagem [serial on line] 2007 Set-Dez; 9(3): 574-587. Available from: URL: http://www.fen.ufg. br/revista/v9/n3/v9n3a02.htm

PI: "But why don't you have time? Is it because of work?"

Flor: "Yes, because [of] school and work."

\section{Theme II I: "Air we breathe"}

Healthy and unhealthy air was described by most participants; sources of harmful air, or air pollution, included occupational and automobile. Healthy air was viewed by some, who compared the visual air quality with what they had observed or experienced in Mexico. The lack of air pollution in the U.S. was noted by Mario who photographed freeway traffic and a blue sky above. He described the trees he photographed in his neighborhood as healthy and contributing to good air quality for him. He also photographed car exhaust and neighborhood litter to demonstrate conflicting environmental influences surrounding him.

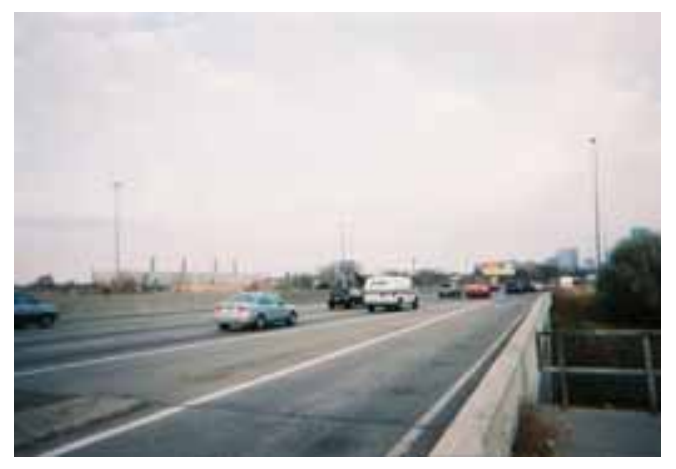

Figure 3: Blue sky, clean air

Liselle pointed out the harmful effects of air pollution from a nearby manufacturing plant, "...with the smog they contaminate the air, everything we breathe, the air we inhale and exhale and that is what makes us healthy or unhealthy." She went on to clarify that she did not live near factors but that if she did, she was sure she would be breathing contaminated air and would experience specific health problems with her kidneys.

Picturing a family enjoying a picnic, Maria shared about what she perceived, "The family they go out and get fun. It's good. That's relaxing. Like not a lot of smog. It's healthy."

\section{Theme IV: "Relaxation in nature"}

Access to recreational parks, nature trails, and lakes was pictured and described as a positive contributor to mental health and physical health with concurrent opportunities to relax and exercise. Miguel took pictures of flowers in the park because he felt the scent and visual aspects of the flowers helped make him feel good, including his self-esteem. His pictures also focused heavily on a variety of exercise venues available at a local urban park, including canoeing, paddle boating, running, biking, and fishing. Other participants also emphasized physical exercise within a park setting in their pictures, describing mental and emotional benefits derived in addition to the physical benefits. Maria described benefits of a park including to "use it to run, to go for walks and to do exercises." Liselle shared,

"I took these pictures, as you can see they relate to each other, because exercising, whether it is walking, running, gymnastics, sports, and all that, and good communication, 
Garcia CM, Medeiros M. Air, water, land: mexican-origin adolescents' perceptions of health and the environment. Revista Eletrônica de Enfermagem [serial on line] 2007 Set-Dez; 9(3): 574-587. Available from: URL: http://www.fen.ufg. br/revista/v9/n3/v9n3a02.htm

that is family unity [picture of family at a park], can help us lead a better life. If we can put aside our thoughts and for a while we go outside of our daily routine. . . that is to lead a better life."

When probed, Liselle elaborated on the nature and relaxation gained from exercise in a park setting rather than simply doing

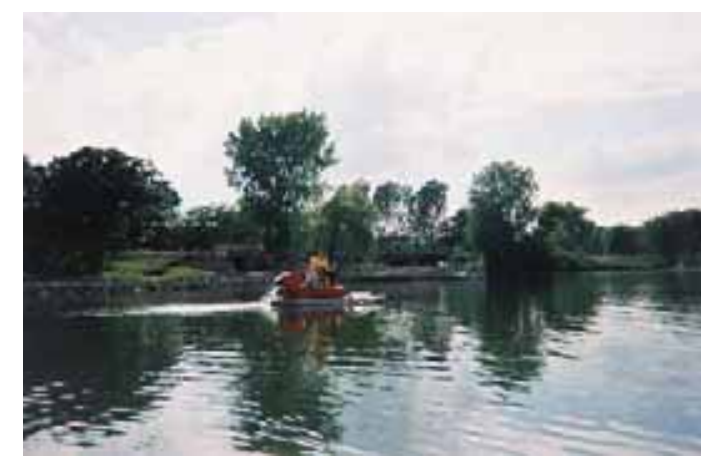

Figure 4: Park recreation

Linking the mental and physical benefits, Jose shared, "canoeing is healthy too and relaxing and is a little bit romantic."

Despite all participants residing in urban settings surrounded by parks, some did not experience or demonstrate opportunity to find and use the recreation areas near them. Citing safety and lack of knowledge of resources, Esmiralda summarized her current physical exercise, "Actually I just walk and when I was in Mexico I used to practice sports. I'm looking for a place to go." In her situation, she wanted to play soccer in the U.S. but did not know how to find a community center or place where she could play.

\section{DISCUSSION}

Social determinants of health include important environmental determinants recognized and described by immigrant Latino something on one's own home: "I am not talking about regular walks. Yes, you can take regular walks but the ones that help clear your mind are the ones like a nature walk, through nature taking a walk by yourself. Those are the types of things that help you mentally. Not a walk or on a machine."

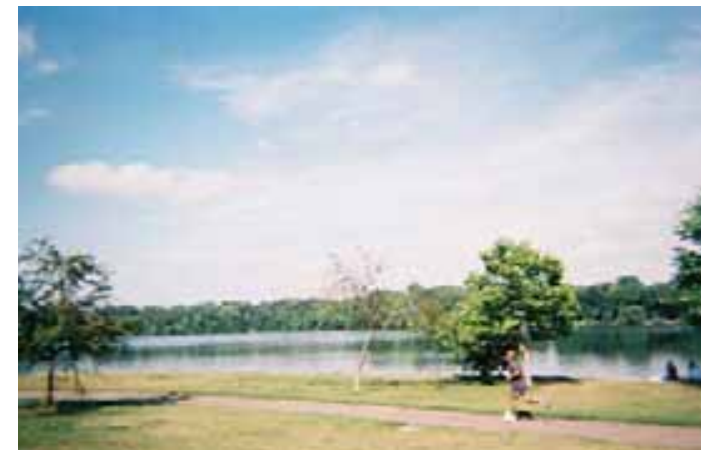

Figure 5: Exercise in nature

adolescents. ${ }^{3,4,12}$ The participants in this study demonstrated acute awareness of harmful and beneficial environmental influences on their physical and mental health. The identified asset, or protective nature, of environmental resources such as lakes and parks for physical and mental health are supported with literature that identifies health problems and disparities associated when these protective environmental factors are absent. ${ }^{2,12}$ In addition, health risks resulting from environmental hazards ranging from pollution and garbage to occupational hazards have been linked to prevalent diseases in the Latino community such as asthma that warrant attention and intervention (1,3,4). Though unaware of an existing ecological theoretical framework, the adolescents provided photographs and stories about environmental risks and assets in the Microsystems 
Garcia CM, Medeiros M. Air, water, land: mexican-origin adolescents' perceptions of health and the environment. Revista Eletrônica de Enfermagem [serial on line] 2007 Set-Dez; 9(3): 574-587. Available from: URL: http://www.fen.ufg. br/revista/v9/n3/v9n3a02.htm

surrounding them, including family, neighborhood, school, and places of employment, worship, and recreation. For some of the adolescents, the Microsystems provided complimentary protective environmental resources while for others the systems compounded risk. Set within the broader ecological context, these environmental influences may be further exaggerated by Ecosystem deficits such as limited access to health care services including health screening, assessment, and education and Macrosystem challenges such as conflicting cultural values with the majority culture. Use of an ecological framework facilitates the ability of nursing to proactively and strategically influence the health and well-being of immigrant Latino adolescents at the varied system levels.

\section{Strengths and limitations}

A strength of this study is that it was conducted with community engagement and support; Latino community members informed the design, implementation, analysis, and dissemination of findings. Recruiting from nonhealth based community settings avoided possible bias toward health-based responses; in addition, not being solely school-based allowed for participation of Latino adolescents who were not in school due to drop-out. A homogenous sampling approach strengths study validity; this approach is recommended in the literature addressing research with Latino sub-groups (20). The use of photovoice strengthened the study design and subsequent data collected, which would have been more limited with an interview only approach. Limitations of the study include self-selection to participate, reduced transferability to nonCentral Mexican immigrant Latino adolescent populations, use of an interpreter, and settings solely based in an urban Mid-western state environment.

\section{Practice recommendations}

Nurses assessing the health concerns of Latino adolescents should holistically consider causal or contributing environmental risks. Asking about employment should lead nurses to examine possible occupational risks or hazards for Latino adolescents. Holistic clinical assessments could improve diagnosis and treatment of environment-exacerbated conditions such as asthma, hearing loss, and depression. Nursing health promotion resources should include environmental assets, when available, including parks, lakes, playgrounds, and trails. Latino adolescents, and their families, will benefit from information provided by nurses, especially when they are recently immigrated and may be experiencing isolation or uncertainty of where environmental resources are and how to access them.

For those who reside in low-income or impoverished areas, environmental resources such as parks or lakes are important protective assets to bring awareness to because they typically are accessible at no cost and in urban areas, may be accessible using public transportation. Encouraging use of these environmental resources serves many purposes, including the more obvious physical and mental health promotion results and the not so obvious but important outcomes such as facilitating family connectedness and communication when family can find relaxation and recreation in a common area like a park. 
Garcia CM, Medeiros M. Air, water, land: mexican-origin adolescents' perceptions of health and the environment. Revista Eletrônica de Enfermagem [serial on line] 2007 Set-Dez; 9(3): 574-587. Available from: URL: http://www.fen.ufg. br/revista/v9/n3/v9n3a02.htm

Finally, consider the contributions adolescents can make in community assessment, activism and empowerment endeavors through the use of photovoice. Photovoice is a tool useful to these processes and one that adolescents eagerly engage ${ }^{(18,19)}$.

\section{Theory development}

This study contributes to the knowledge base of application of the ecological framework in nursing research with Latino adolescents. The discipline of Nursing with its holistic perspective makes nursing an ideal discipline to build upon Bronfenbrenner's work and explicate an ecological model for individual/family, community, and system health and health promotion.

\section{RESEARCH RECOMMENDATI ONS}

Further research should build on this descriptive work to examine environmental influences on the physical and mental health of Latino adolescents, including occupational, residential, and community environmental risks and assets. Studies employing neighborhood mapping and GPS strategies to examine health disparities experienced in Latino dominant communities should incorporate assessment of natural environmental factors and not be limited solely to assessing the presence or absence of physical environment risks such as liquor stores.

Researchers should employ methodologies that encourage participant creativity, such as visual narratives, so that optimal data are obtained. This could be especially relevant for research involving adolescents, who might experience feelings of powerlessness in more traditional research strategies such as interviews. Further, for English Language Learners (ELL), photovoice might be an appealing data collection strategy that is not dependent on speaking, reading or writing abilities. When the research question can be answered in part or fully through use of photovoice, the method should be critically examined and considered.

Health promotion research with Latino adolescents should consider incorporating environmental components to intervention strategies in order to optimize positive outcomes such as family connectedness, physical health, and mental health.

\section{CONCLUSION}

In conclusion, this study contributes to understanding in nursing regarding the health of immigrant Latino adolescents and specifically, the environmental factors that influence or have the potential to influence their physical and mental well-being. Nursing is poised to creatively build on this descriptive research to inform health promotion interventions designed using an ecological framework. Photovoice is a useful tool for nursing practice and research with many populations, including immigrant Latino adolescents. Nursing practice and research can act upon the study findings to holistically assess and intervene to promote health and reduce environmental risks experienced by immigrant Latino youth. These efforts and actions can positively influence the health of immigrant Latino adolescents, working toward eliminating health disparities experienced here in the U.S.

\section{REFERENCES}


Garcia CM, Medeiros M. Air, water, land: mexican-origin adolescents' perceptions of health and the environment. Revista Eletrônica de Enfermagem [serial on line] 2007 Set-Dez; 9(3): 574-587. Available from: URL: http://www.fen.ufg. br/revista/v9/n3/v9n3a02.htm

1. Berg J, Wahlgren DR, Hofstetter CR, et al. Latino children with asthma: Rates and risks for medical care utilization. J Asthma. 2004; 41: 147-157.

2. Plunkett SW, Abarca-Mortensen S, Behnke AO, Sands T. Neighborhood structural qualities, adolescents' perceptions of neighborhoods, and latino youth development. Hispanic Journal of Behavioral Sciences. 2007; 29: 19-34.

3. Salazar MK, Napolitano M, Scherer JA, McCauley LA. Hispanic adolescent farmworkers' perceptions associated with pesticide exposure. West J Nurs Res. 2004; 26:146-66; discussion 167-75.

4. Wilson AH, Pittman K, Wold J L. Listening to the quiet voices of hispanic migrant children about health. J Pediatr Nurs. 2000; 15:137147.

5. Bendersky M, Lewis M. Environmental risk, biological risk, and developmental outcome. Dev Psychol. 1994; 30:484-494.

6. Zahn-Waxler C. Environment, biology, and culture: Implications for adolescent development. Dev Psychol. 1996; 32:571-573.

7. Golub MS. Adolescent health and the environment. Environ Health Perspect. 2000; 108:355-362.

8. Crowley M, Lichter DT, Qian Z. Beyond gateway cities: Economic restructuring and poverty among mexican immigrant families and children doi: $10.1111 / \mathrm{j} .1741$ 3729.2006.00407.x. Family Relations. 2006; 55: 345-360.

9. DeNavas-Walat C, Proctor BD, Hill Lee C. Income, poverty, and health insurance coverage in the united states: 2005. 2006; P60-231.

10. Tolan PH, Gorman-Smith D, Henry DB. The developmental ecology of urban males' youth violence. Dev Psychol. 2003; 39:274-291.

11. Marquez DX, McAuley E, Overman N. Psychosocial correlates and outcomes of physical activity among latinos: A review. Hispanic Journal of Behavioral Sciences. 2004; 26: 195-229.

12. Humbert ML, Chad KE, Spink KS, et al. Factors that influence physical activity participation among high- and low-SES youth. Qual Health Res. 2006; 16:467-483.

13. Streng J, Rhodes S, Ayala G, Eng E, Arceo R, Phipps S. Realidad Latina: Latino adolescents, their school, and a university use photovoice to examine and address the influence of immigration. Journal of Interprofessional Care. 2004; 18:403-415.

14. Bronfenbrenner U. The Ecology of Human Development: Experiments by Nature and
Design. Cambridge: Harvard University Press; 1979.

15. Garcia C, Duckett L, Saewyc E, Bearinger L. Perceptions of health among immigrant Latino adolescents from Mexico. Journal of Holistic Nursing. 2007; 25(2):81-91.

16. Garcia C, Saewyc. Perceptions of mental health among recently immigrated Mexican adolescents. Issues in Mental Health Nursing. 2007; 28: 37-54.

17. Morse J, Field PA. Qualitative Research Methods for Health Professionals. Thousand Oaks: Sage Publications, Inc; 1995.

18. Wang C, Burris M. Photovoice: Concept, methodology, and use for participatory needs assessment. Health Education and Behavior. 1997; 24:369-387.

19. Medeiros, M. Olhando a lua pelo mundo da rua: representações sociais da experiência de vida de meninos em situação de rua. [Doutorado]. Ribeirão Preto, SP: Escola de Enfermagem de Ribeirão Preto da Universidade de São Paulo. 1999. [cited on 20 Aug 2007]. Available from URL: http://www.teses.usp.br/teses/disponiveis/83/ 83131/tde-25022003-082739/.

20. Weinick RM, Jacobs EA, Stone LC, Ortega AN, Burstin H. Hispanic healthcare disparities: Challenging the myth of a monolithic hispanic population. Med Care. 2004; 42:313-320.

Artigo recebido em 10.07.07

Aprovado para publicação em 10.12.07

\section{Notes}

Thank you to the adolescents who graciously participated in this research. Thank you to my research advisors and mentors, including Drs. Laura Duckett, Linda H. Bearinger, Elizabeth Saewyc, and Michael Resnick. This research was supported in part by the SAM Career Development Award, grants R03 MC 01029-0101, T80 MC00021-13 and T71 MC00025-01 from the Maternal and Child Health Bureau, Health Resources and Services Administration, Department of Health and Human Services; grants T01 DP000112-02 and U48 CCCU513331 from the Centers for Disease Control and Prevention; and grants from the University of Minnesota Graduate School and Zeta Chapter of Sigma Theta Tau International. 